\title{
1 Carbon sequestration on Mars
}

2 Christopher S. Edwards ${ }^{1 *}$ and Bethany L. EhImann ${ }^{1,2}$

$3{ }^{1}$ California Institute of Technology,1200 E. California Boulevard, MC 150-21, Pasadena,

4 California 91125, USA

$5 \quad{ }^{2}$ Jet Propulsion Laboratory/ California Institute of Technology, Pasadena, California

6 91109, USA

$7 \quad *$ Current address: U.S. Geological Survey Astrogeology Science Center, 2255 N. Gemini

8 Road, Flagstaff, Arizona 86001, USA. 


\section{ABSTRACT}

11 On Earth, carbon sequestration in geologic units plays an important role in the

12 carbon cycle, scrubbing $\mathrm{CO}_{2}$ from the atmosphere for long-term storage. While identified

13 in low abundances within the dust and soils, at $<1 \mathrm{wt} \%$ in select meteorites, and in

14 limited outcrops, no massive carbonate rock reservoir on Mars has been identified to

15 date. Here, we investigate the largest exposed carbonate-bearing rock unit, the Nili

16 Fossae plains, combining spectral, thermophysical and morphological analyses to

17 evaluate the timing and carbon sequestration potential of rocks on Mars. We find the

18 olivine-enriched ( $20 \%-25 \%)$ basalts have been altered, by low-temperature, in-situ

19 carbonation processes, to at most $\sim 20 \% \mathrm{Fe}-\mathrm{Mg}$ carbonate, thus limiting carbon

20 sequestration in the Nili Fossae region to $\sim 0.25-12$ mbar of $\mathrm{CO}_{2}$ during the late

21 Noachian/early Hesperian, before or concurrent with valley network formation. While

22 large compared to modern-day $\mathrm{CO}_{2}$ reservoirs, the lack of additional, comparable-sized

23 post-Late Noachian carbonate-bearing deposits on Mars indicates ineffective carbon

24 sequestration in rock units over the past $\sim 3.7 \mathrm{Ga}$. This implies a thin atmosphere ( $\$ 500$

25 mbar) during valley network formation, extensive post-Noachian atmospheric loss to

26 space or diffuse, deep sequestration by a yet-to-be understood process. In stark contrast to

27 Earth's biologically mediated crust:atmosphere carbon reservoir ratio of $\sim 10^{4}-10^{5}$, Mars'

28 ratio is a mere $10-10^{3}$, even if buried pre-Noachian crust holds multiple bars. 


\section{INTRODUCTION}

31 Martian carbonates have been observed telescopically, from orbit (e.g., Bandfield

32 et al., 2003; Ehlmann et al., 2008; Michalski and Niles, 2010), in situ (e.g., Boynton et

33 al., 2009; Morris et al., 2010) and in Martian meteorites; however, a long-postulated

34 geologic reservoir that accounts for proposed thinning of a multi-bar early Mars

35 atmosphere by $\mathrm{CO}_{2}$ sequestration (Booth and Kieffer, 1978; Pollack et al., 1987) has not

36 yet been identified (Niles et al., 2013). One striking aspect of the Martian geologic record

37 is the presence of valley networks and open basin lakes last active around the

38 Noachian/Hesperian boundary, at ca. 3.5 Ga (Fassett and Head, 2008). If surface waters

39 were supported by a thicker atmosphere (Hynek et al., 2010), hundreds of millibars to

40 bars of $\mathrm{CO}_{2}$ would need to be lost to space during the Hesperian/Amazonian, inconsistent

41 with models (e.g., Lammer et al., 2013). Was this late $\mathrm{CO}_{2}$ sequestered in the Martian

42 crust? We consider the role of diffuse and localized $\mathrm{CO}_{2}$ sequestration and constrain the

43 timing/implications for late Noachian atmospheric conditions via examination of the age

44 and composition of the largest contiguous exposure of carbonate-bearing rock on Mars,

45 the Nili Fossae carbonate plains $\left(21.5^{\circ} \mathrm{N}, 78.5^{\circ} \mathrm{E}\right.$; Ehlmann et al., 2008). Morphological,

46 spectral and thermophysical data sets, Thermal Emission Spectrometer (TES), Compact

47 Reconnaissance Imaging Spectrometer for Mars (CRISM), Thermal Emission Imaging

48 System (THEMIS), Context Imager (CTX) and High Resolution Imaging Science

49 Experiment (HiRISE) are considered in the context of past atmospheric drawdown.

\section{MINERAL MAPPING AND ABUNDANCES}

51 At a scale of kilometers, we map two distinct TES spectral units using the

52 carbonate decomposition product/carbonate index (Fig. 1; Table DR1; Glotch and 


\section{Geology, 2015, doi: 10.1130/G36983.1}

Accepted, Pre-Copy Edit version

53 Rogers, 2013). Basaltic terrains $\left(\right.$ TES $\left.^{\mathrm{C}}\right)$ have low carbonate $(\sim 10 \%)$, low olivine $(\sim 4 \%)$,

54 and elevated feldspar/pyroxene abundances similar to Syrtis Major (Rogers and

55 Christensen, 2007). In contrast, $\mathrm{TES}^{\mathrm{A} \& \mathrm{~B}}$ have elevated Fe-Mg carbonate $(\sim 15 \%), \sim 20 \%$

56 olivine ( Fo60-70; Hamilton and Christensen, 2005), and comparable pyroxene but

57 substantially less feldspar. Carbonate is close to the detection limit for $\mathrm{TES}^{\mathrm{C}}$ and $\mathrm{TES}^{\mathrm{A \& B}}$;

58 however, TES ${ }^{\mathrm{A} \& \mathrm{~B}}$ spectral model fits (specifically the $\sim 350 \mathrm{~cm}^{-1}$ feature) are improved by

59 the additional $\sim 5 \%$ carbonate and are not well matched by increases in other mafic

60 minerals with absorptions at these wavelengths. High-Si phases are elevated $(\sim 20 \%)$ in

61 all TES spectra, likely evidence of the aqueous alteration prevalent in the region

62 (Mangold et al., 2007; Rogers and Christensen, 2007). Carbonate content of $\sim 5 \%$ is a

63 minimum as the TES footprints are a combination of carbonate and non-carbonate

64 bearing materials observed at finer-scales (CRISM, HiRISE; Figs. 2 and 3).

65 Five distinct CRISM spectral units are identified (Fig. 2), correlated with

66 morphology (Fig. 3): (1) low-albedo, olivine-bearing basaltic bedrock; (2) olivine-

67 enriched basaltic sands; (3) olivine/carbonate-bearing basaltic bedrock; (4) a basaltic

68 capping unit; and (5) an Fe-Mg smectite-bearing Noachian basement (not investigated

69 here, see Ehlmann et al., 2009; Mustard et al., 2009). Spectra from morphological units

70 (1-3) have similar spectral shapes around $\sim 1 \mu \mathrm{m}$ (Fig. 2b), distinct from (4) and

71 consistent with intermediate $\mathrm{Fo}_{\#}$ and/or large grain size olivine.

72 Hapke modeling of single scattering albedo (SSA) spectra extracted from

73 DISORT-processed CRISM data yields mineral abundances and grain sizes (Table DR2;

74 Fig. 2). The carbonate-bearing unit (3) has $\sim 15 \%$ (1 mm grain size) carbonate in an

75 olivine-enriched $(\sim 25 \%, \sim 1 \mathrm{~mm})$ basalt $(\sim 60 \%, \sim 1 \mathrm{~mm})$, with minimal Fe-Mg smectite 


\section{Geology, 2015, doi: 10.1130/G36983.1}

\section{Accepted, Pre-Copy Edit version}

76 (<2\%). Other olivine-bearing units (1-2) have $\sim 20 \%-30 \%$ olivine and are coarse-grained

77 ( $\sim 1 \mathrm{~mm})$ with $\sim 60 \%$ basalt and negligible carbonate. The basaltic cap unit (4) is distinct,

78 composed mostly of a finer-grained $(\sim 400 \mu \mathrm{m})$ basaltic material with little olivine or

79 smectite. A second modeling approach with scene-derived olivine bedrock SSA (unit 3)

80 and lab-derived carbonate SSA indicates $\sim 5 \%$ carbonate, using the observed depth of the

$812.5 \mu \mathrm{m}$ absorption (the most unique indicator of carbonate; Ehlmann et al., 2008) (Fig

82 DR1).

83 THEMIS band 7 band depth is correlated with the CRISM OLINDEX2 (olivine

84 index). THEMIS ratio data show a downturn in bands $1 / 2$ correlated with and coincident

85 with locations where CRISM shows the strongest band depths at 2.3 and $2.5 \mu \mathrm{m}$ (Fig. 4;

86 Fig. DR2). An olivine-carbonate mixture and olivine spectra are good matches for the

87 ratio spectra extracted from spatially coherent THEMIS data (Fig. 4b).

\section{MORPHOLOGY}

89 Carbonate abundance is anti-correlated with the presence of the olivine-bearing

90 sand cover (Fig. 2c). The carbonate-bearing unit is highly fractured and light-toned with

91 darker, fracture-filling materials (likely sand; Fig. 3b). The carbonate-poor/olivine-

92 bearing outcrops exhibit a rough and pitted texture and typically lie stratigraphically

93 above the olivine-/carbonate-bearing unit with a seemingly conformable contact (Fig.

94 3b). Notably, the carbonate-poor/olivine-bearing rock is morphologically distinct from

95 the capping unit, which has a massive appearance (Fig. 3).

96 PHYSICAL PROPERTIES

97 Regional thermal inertia (TI) ranges from $\sim 250$ to $600 \mathrm{~J} \mathrm{~m}^{-2} \mathrm{~K}^{-1} \mathrm{~s}^{-1 / 2}$ (hereafter

$98 \mathrm{SI})$, corresponding to grain sizes from fine regolith $(\sim 300 \mu \mathrm{m})$ to weakly 


\section{Geology, 2015, doi: 10.1130/G36983.1}

Accepted, Pre-Copy Edit version

99 consolidated/heavily altered bedrock ( $>1 \mathrm{~mm})$, inconsistent with crystalline Martian

100 volcanics (>1200 SI in THEMIS; Edwards et al., 2009). Surface materials (e.g., aeolian

101 bedforms, dust) can reduce derived TI, but many clean exposures are observed at HiRISE

102 scales.

103 The thermophysical and compositional characteristics show distinct groupings.

104 The olivine-/carbonate-bearing materials typically have TI of $\sim 400-500$ SI (Fig. 2; Fig.

105 DR3), and the $\sim 10 \%$ higher TI in olivine-bearing/carbonate-poor materials can be

106 explained solely by their lower albedos below the spatial scale used in TI modeling

107 (Fergason et al., 2006a). Olivine-basalt sands have TI of $\sim 350$ SI ( $\gtrsim 1 \mathrm{~mm}$ grains), while

108 the low-olivine capping unit has TI of 250-300 SI ( 300-700 $\mu \mathrm{m}$ grains; Fig. 2d; Fig.

109 DR3a; Piqueux and Christensen, 2011), consistent with CRISM-derived grain sizes.

110 GEOLOGIC HISTORY AND ENVIRONMENTAL IMPLICATIONS

111 Olivine abundances (20\%-25\%) suggest the olivine-bearing basalts in Nili Fossae

112 are likely picritic, resembling the Adirondack rock class from Gusev (McSween et al.,

113 2006). Previously, the olivine-bearing materials were interpreted as olivine-enriched

114 basalt flows (Hamilton and Christensen, 2005) predating the Isidis impact or cumulates

115 settled from the Isidis-derived impact melt sheet (Mustard et al., 2009). However, the low

116 TI of these unmantled olivine-enriched units is inconsistent with crystalline igneous rocks

117 (e.g., Adirondack) but is similar to that of the clastic olivine/-carbonate-bearing rocks

118 (Comanche/Algonquin classes, 550 SI) observed in the Columbia Hills (Fig. 1b;

119 Fergason et al., 2006b; Ruff et al., 2014) or highly fractured materials. The basaltic

120 capping unit, while forming significant topographic highs, has the lowest TI ( $\sim 300 \mathrm{SI})$. 


\section{Geology, 2015, doi: 10.1130/G36983.1}

\section{Accepted, Pre-Copy Edit version}

121 Its distinct composition, morphology and thermophysical properties suggest that it may

122 be an eroded ash deposit (e.g., Bandfield et al., 2013).

123 The olivine-enriched and olivine-/carbonate-enriched units are likely the same

124 original lithology, given their similar compositions (except for Mg-Fe carbonate),

125 morphology and TI. Their low TI suggests a clastic rock or pervasive fracturing at $\mathrm{cm}-$

126 scale in a crystalline igneous rock. Given the fractures observed (advantageous for fluids

127 to migrate more easily) and mineral assemblages/abundances, we find the likely scenario

128 for the formation of the Nili Fossae carbonate plains is low-temperature, in situ

129 carbonation (van Berk and Fu, 2011), akin to the Samail ophiolite in Oman (Kelemen and

130 Matter, 2008) or in-place serpentinization reactions. Variability of fractures/pore-space in

131 the precursor rock or limited groundwater percolation may produce the spatial variability

132 of carbonate-bearing outcrops, leaving some regions largely unaltered.

133 Of critical importance is the timing of carbonation and atmospheric $\mathrm{CO}_{2}$

134 sequestration in the Nili Fossae and in other potential reservoirs. Sequestration in Nili

135 Fossae must have occurred after emplacement of the olivine-rich precursor (syn- or post-

136 Isidis formation, i.e., early/middle Noachian; Hamilton and Christensen, 2005; Mustard

137 et al., 2009). The carbonate-bearing units are incised by valley networks and overlain by

138 the Hesperian Syrtis Major unit, indicating carbonation prior to or contemporaneous with

139 valley network formation. This important local timing constraint can be extended

140 globally, as $>50 \%$ of the Mars surface is comprised of Noachian and Hesperian terrains

141 of similar age or younger than Isidis (Tanaka et al., 2014). The lack of additional late

142 Noachian and younger carbonate-bearing units is not likely a sampling bias as a host of

143 other secondary minerals are observed (Ehlmann and Edwards, 2014). 


\section{POTENTIAL}

146 TES and CRISM locations with elevated carbonate spatially correlate, and

147 quantitative modeling agrees on total carbonate $(\sim 5 \%-15 \%)$ and relative differences in

148 carbonate abundance $(\sim 5 \%-15 \%)$. In the inverse model, the diagnostic $2.5-\mu \mathrm{m}$ absorption

149 is overmodeled (Fig. 2b), favoring the $\sim 5 \%$ CRISM-derived carbonate abundance from

150 forward modeling (Fig. S1). Checkerboard mixing of olivine-basaltic sands at sub-

151 CRISM pixel scales lowers the apparent carbonate abundance; though HiRISE 25

$152 \mathrm{~cm} /$ pixel data suggest $>75 \%$ of the surface is clean. By coupling HiRISE to TES/CRISM

153 abundances, our work indicates $\sim 20 \%$ carbonate is a likely maximum for Nili Fossae

154 carbonate plains bedrock. The areal extent of the unit is constrained using only carbonate-

155 bearing outcrop exposures $\left(\sim 6800 \mathrm{~km}^{2}\right)$ or the entire extent of the regional Nili Fossae

156 olivine outcrops $\left(300,000 \mathrm{~km}^{2}\right)$ that are variably buried by Syrtis lavas. Depth is

157 constrained by a 6-km-diameter impact crater excavating $\sim 500 \mathrm{~m}$ and beneath the

158 carbonate $\left(21.35^{\circ} \mathrm{N}, 78.80^{\circ} \mathrm{E}\right)$, previous estimates for the thickness of the olivine-bearing

159 unit (Mustard et al., 2009), and the typical depth of in situ carbonation ( $\$ 200 \mathrm{~m}$; van

160 Berk and Fu, 2011). Thus, the Nili Fossae carbonate plains unit likely sequestered $\sim 0.25-$

16112 mbars of atmospheric $\mathrm{CO}_{2}\left(\sim 4 \times 10^{-4}\right.$ mbar of $\mathrm{CO}_{2}$ per $\mathrm{km}^{3}$ of $\left.\mathrm{MgCO}_{3}\right)$.

162 The $\mathrm{CO}_{2}$ sequestered in the Nili Fossae is significant relative to the current $\sim 6$

163 mbar atmosphere, $\mathrm{CO}_{2}$ within the south polar cap (5 mbar; Phillips et al., 2011), and that

164 sequestered in the ubiquitous Martian dust ( $\sim 1$ mbar for $\sim 5 \%$ abundance, $\sim 1 \mathrm{~m}$ thick

165 global layer of $40 \%$ porosity; Bandfield et al., 2003). However, it is small relative to the

166 hundreds of millibars to bars of $\mathrm{CO}_{2}$ suggested to sustain surface waters during late 


\section{Geology, 2015, doi: 10.1130/G36983.1 \\ Accepted, Pre-Copy Edit version}

167 Noachian/early Hesperian valley network formation. If carbon sequestration occurred by

168 carbonate mineralization and $\gtrsim 500$ mbar late-Noachian atmosphere was removed, either

169 post-Noachian carbonate formation is more volumetrically widespread but diffuse than

170 has been observed in landed missions and meteorites or $>35$ "hidden" Nili Fossae-scale

171 post-Noachian carbonate-bearing rock deposits remain to be discovered.

172 While orbital remote sensing could miss small-scale deposits (e.g., Ruff et al.,

173 2014), given the mineralogical discrimination and spatial coverage, it is unlikely that

174 many significant reservoirs of Nili Fossae-scale and age (or younger) have been

175 overlooked. Remote sensing data cannot exclude early- or pre-Noachian formation of

176 carbonate bearing rocks (e.g., Michalski and Niles, 2010; Niles et al., 2013, and

177 references therein) as these early- and pre-Noachian are deeply buried, exposed over

$178<10 \%$ of the surface (Tanaka et al., 2014) and tapped only infrequently by impact craters.

179 However, if an early-/pre-Noachian episode of carbon sequestration occurred, it pre-dates

180 formation of Mars' valley networks and hence cannot explain removal of a thick

181 atmosphere that may have enabled precipitation at that time.

182 Destruction of carbonates by acid waters cannot resolve the paradox of the

183 missing carbon reservoir because dissolution would release $\mathrm{CO}_{2}$ back into the

184 atmosphere, i.e., a recycling resulting in no net carbon sequestration. Post Noachian

185 deep-diffuse alteration could, however, be undetectable by remote sensing. For example,

186 the Nakhlites and ALH84001 contain trace carbonates. Martian missions investigating

187 equatorial geologic units have found carbonate at $<2 \%$ in rocks and soils (e.g., Leshin et

188 al., 2013), and the Phoenix lander found soil carbonates at 5\% (Boynton et al., 2009).

189 To sequester $\sim 500$ mbar of atmospheric $\mathrm{CO}_{2}$, the crust would have to be altered at an 


\section{Geology, 2015, doi: 10.1130/G36983.1}

Accepted, Pre-Copy Edit version

190 average of $1 \mathrm{wt} \%$ to a depth of $\sim 1 \mathrm{~km}$. Sequestering carbon this deep in the crust is

191 challenging; open hydrologic systems do not typically support alteration to great depths

192 ( $\lesssim 100$ s of meters; van Berk and $\mathrm{Fu}, 2011)$ because atmospherically derived $\mathrm{CO}_{2}$ in fluids

193 is exhausted by mineralization, ultimately limiting carbon sequestration potential from

194 deep, diffuse processes.

195 Modern Martian carbon sequestration may be prevented in most locations by

196 either aridity, acidity, or sulfurous gases that inhibit carbonate formation (Halevy and

197 Schrag, 2009). Either an efficient water-driven "pumping" of $\mathrm{CO}_{2}$ down into the

198 subsurface for deep diffuse carbon sequestration or vigorous, post-Noachian atmospheric

199 escape to space would be required to remove a late Noachian hundreds of millibars to

200 multi-bar $\mathrm{CO}_{2}$ atmosphere. These high escape rates later in Mars history are not expected

201 (Lammer et al., 2013), but the MAVEN mission will lead to an improved quantification

202 of average loss rates. Possibly most likely, the $p \mathrm{CO}_{2}$ of the post-Noachian atmosphere

203 was simply low, even during the time of valley network formation. If this hypothesis is

204 correct, the isotopic record of $\mathrm{CO}_{2}$ should be consistent with loss predominantly to the

205 atmosphere over time and no major crustal carbon sequestration since the early Noachian.

206 Notably, even if multiple bars of sequestration are assumed for buried pre-Noachian

207 units, the Martian rock reservoir contains only $10-10^{3}$ times the carbon in the

208 atmosphere, in stark contrast to the $\sim 10^{4}-10^{5}$ ratio for Earth, a consequence of effective,

209 biologically driven carbon sequestration (Ronov and Yaroshevsky, 1969). Continued

210 evaluation of carbonate in Martian meteorites and in situ analysis of chemistry,

211 mineralogy and isotopic composition of carbonate-bearing rocks will generate new data

212 to determine the long-term evolution of carbon geochemical cycling on Mars. 


\section{ACKNOWLEDGMENTS}

We thank R.E. Arvidson for providing the CRISM DISORT processed image,

215 A.D. Rogers the Syrtis-type TES spectra, and S. Piqueux for helpful discussions. T.D.

216 Glotch, P. D. Niles, and an anonymous reviewer provided helpful formal reviews. A

217 Mars Exploration Program Future Landing Sites grant administered by the Jet

218 Propulsion Laboratory provided partial support for Edwards and Ehlmann to conduct 219 this analysis.

220 


\section{REFERENCES CITED}

222 Bandfield, J.L., Edwards, C.S., Montgomery, D.R., and Brand, B.D., 2013, The dual

223 nature of the martian crust: Young lavas and old clastic materials: Icarus, v. 222,

224 p. 188-199, doi:10.1016/j.icarus.2012.10.023.

225 Bandfield, J.L., Glotch, T.D., and Christensen, P.R., 2003, Spectroscopic identification of

226 carbonates in the Martian dust: Science, v. 301, p. 1084, doi:10.1126/science.1088054.

Booth, M.C., and Kieffer, H.H., 1978, Carbonate formation in Mars-like environments: Journal of Geophysical Research, v. 83, B4, p. 1809-1815, doi:10.1029/JB083iB04p01809.

Boynton, W.V., et al., 2009, Evidence for calcium carbonate at the Mars Phoenix landing site: Science, v. 325, p. 61-64, doi:10.1126/science.1172768.

Edwards, C.S., Bandfield, J.L.,Christensen, P.R., and Fergason, R.L., 2009, Global distribution of bedrock exposures on Mars using THEMIS high-resolution thermal

Ehlmann, B.L., and Edwards, C.S., 2014, Mineralogy of the Martian surface: Annual inertia: Journal of Geophysical Research, v. 114, E11001, doi:10.1029/2009JE003363.

Ehlmann, B.L., et al., 2008, Orbital identification of carbonate-bearing rocks on Mars:

241 Science, v. 322, p. 1828, doi:10.1126/science.1164759.

242 Ehlmann, B.L., et al., 2009, Identification of hydrated silicate minerals on Mars using

243 MRO-CRISM: Geologic context near Nili Fossae and implications for aqueous 
245 doi:10.1029/2009JE003339.

246 Fassett, C.I., and Head, J.W., 2008, The timing of martian valley network activity:

247 Constraints from buffered crater counting: Icarus, v. 195, p. 61-89,

248 doi:10.1016/j.icarus.2007.12.009.

249 Fergason, R.L., Christensen, P.R., and Kieffer, H.H., 2006a, High resolution thermal

250 inertia derived from THEMIS: Thermal model and applications: Journal of

251 Geophysical Research, v. 111, E12004, doi:10.1029/2006JE002735.

252 Fergason, R.L., Christensen, P.R., Bell, J.F., III, Golombek, M.P., Herkenhoff, K.E., and

253 Kieffer, H.H., 2006b, Physical properties of the Mars Exploration Rover landing

254 sites as inferred from Mini-TES-derived thermal inertia: Journal of Geophysical

255 Research, v. 111, E02S21, doi:10.1029/2005JE002583.

256 Glotch, T.D., and Rogers, A.D., 2013, Evidence for magma-carbonate interaction beneath

257 Syrtis Major, Mars: Journal of Geophysical Research, v. 118, p. 126-137.

258 Halevy, I., and Schrag, D.P., 2009, Sulfur dioxide inhibits calcium carbonate

259 precipitation: Implications for early Mars and Earth: Geophysical Research Letters,

260 v. 36, L23201, doi:10.1029/2009GL040792.

261 Hamilton, V.E., and Christensen, P.R., 2005, Evidence for extensive olivine-rich bedrock

262 in Nili Fossae, Mars: Geology, v. 33, p. 433-436, doi:10.1130/G21258.1.

263 Hynek, B.M., Beach, M., and Hoke, M.R.T., 2010, Updated global map of Martian valley

264 networks and implications for climate and hydrologic processes: Journal of

265 Geophysical Research, v. 115, E09008, doi:10.1029/2009JE003548. 


\section{Geology, 2015, doi: 10.1130/G36983.1}

\section{Accepted, Pre-Copy Edit version}

266 Kelemen, P.B., and Matter, J., 2008, In situ carbonation of peridotite for $\mathrm{CO}_{2}$ storage:

267 Proceedings of the National Academy of Sciences of the United States of America,

268 v. 105 , p. 17295-17300, doi:10.1073/pnas.0805794105.

269 Lammer, H., et al., 2013, Outgassing history and escape of the martian atmosphere and

270 water inventory: Space Science Reviews, v. 174, p. 113-154, doi:10.1007/s11214-

$271 \quad 012-9943-8$.

272 Leshin, L.A., et al., 2013, Volatile, isotope, and organic analysis of martian fines with the

273 Mars Curiosity rover: Science, v. 341, doi:10.1126/science.1238937.

274 Mangold, N., et al., 2007, Mineralogy of the Nili Fossae region with OMEGA/Mars

275 Express data: 2. Aqueous alteration of the crust: Journal of Geophysical Research,

276 v. 112, E08S04, doi:10.1029/2006JE002835.

277 McSween, H.Y., et al., 2006, Characterization and petrologic interpretation of olivine-

278 rich basalts at Gusev Crater, Mars: Journal of Geophysical Research, v. 111,

$279 \quad$ E02S10, doi:10.1029/2005JE002477.

280 Michalski, J.R., and Niles, P.B., 2010, Deep crustal carbonate rocks exposed by meteor

281 impact on Mars: Nature Geoscience, v. 3, p. 751-755, doi:10.1038/ngeo971.

282 Morris, R.V., et al., 2010, Identification of carbonate-rich outcrops on Mars by the Spirit

283 Rover: Science, v. 329, p. 421-424, doi:10.1126/science.1189667.

284 Mustard, J.F., et al., 2009, Composition, morphology, and stratigraphy of Noachian crust

285 around the Isidis basin: Journal of Geophysical Research, v. 114, E00D12,

286 doi:10.1029/2009JE003349. 


\section{Geology, 2015, doi: 10.1130/G36983.1}

\section{Accepted, Pre-Copy Edit version}

287 Niles, P.B., et al., 2013, Geochemistry of carbonates on Mars: Implications for Climate

288 history and nature of aqueous environments: Space Science Reviews, v. 174, p. 301-

$289 \quad 328$, doi:10.1007/s11214-012-9940-y.

290 Phillips, R.J., et al., 2011, Massive $\mathrm{CO}_{2}$ Ice deposits sequestered in the south polar

291 layered deposits of Mars: Science, v. 332, p. 838-841, doi:10.1126/science.1203091.

292 Piqueux, S., and Christensen, P.R., 2011, Temperature-dependent thermal inertia of

293 homogeneous Martian regolith: Journal of Geophysical Research, v. 116, E07004,

294 doi:10.1029/2011JE003805.

295 Pollack, J.B., et al., 1987, The case for a wet, warm climate on early Mars: Icarus, v. 71,

296 p. 203-224, doi:10.1016/0019-1035(87)90147-3.

297 Rogers, A.D., and Christensen, P.R., 2007, Surface mineralogy of martian low-albedo

298 regions from MGS TES data: Implications for crustal evolution and surface

299 alteration: Journal of Geophysical Research, v. 112, E01003,

300 doi:10.1029/2006JE002727.

301 Ronov, A.B., and Yaroshevsky, A.A., 1969, Chemical Composition of the Earth's Crust,

302 in Hart, P.J., ed., The Earth's Crust and Upper Mantle: Washington, D.C., American

303 Geophysical Union, p. 37-57.

304 Ruff, S.W., Niles, P.B., Alfano, F., and Clarke, A.B., 2014, Evidence for a Noachian-

305 aged ephemeral lake in Gusev crater, Mars: Geology, v. 42, p. 359-362,

306 doi:10.1130/G35508.1.

307 Tanaka, K.L., et al., 2014, Geologic Map of Mars: U.S. Geologic Survey Scientific

308 Investigations Map 3292, scale 1:20,000,000, with 43 p. pamphlet. 


\section{Geology, 2015, doi: 10.1130/G36983.1 \\ Accepted, Pre-Copy Edit version}

309 van Berk, W., and Fu, Y., 2011, Reproducing hydrogeochemical conditions triggering the

310 formation of carbonate and phyllosilicate alteration mineral assemblages on Mars

311 (Nili Fossae region): Journal of Geophysical Research, v. 116, E10006,

312 doi:10.1029/2011JE003886.

313 


\section{FIGURE CAPTIONS}
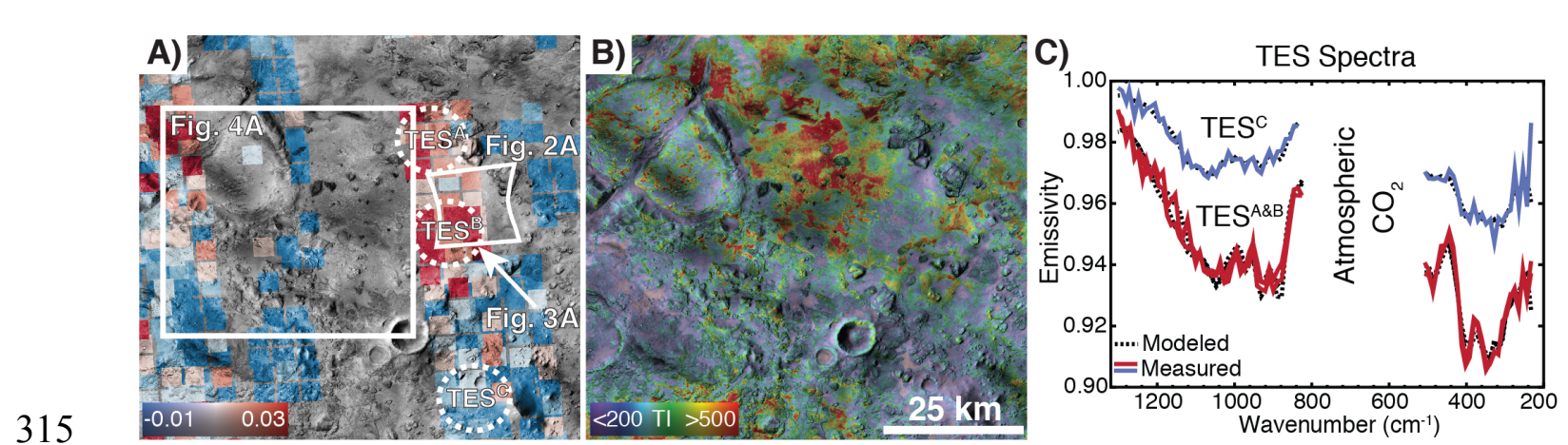

316 Figure 1. A: TES carbonate decomposition product/carbonate index (Glotch and Rogers,

$3172013)$ over a CTX mosaic $\left(6 \mathrm{~m} / \mathrm{px}, \sim 21.5^{\circ} \mathrm{N}, 78.5^{\circ} \mathrm{E}\right)$ highlights locations with carbonate

318 which are of moderate TI in (B) THEMIS TI over a CTX mosaic. C: TES spectral

319 observations (OCK 3358) corresponding to the locations in A. TES ${ }^{\mathrm{C}}$ is consistent with

320 typical Syrtis Major compositions. TES ${ }^{\mathrm{A} \& \mathrm{~B}}$ have increases in both olivine $(\sim 23 \%)$ and

321 Fe-Mg carbonate $(\sim 15 \%)$ over TES ${ }^{\mathrm{C}}$. Abundances are detailed in Table DR1 and the

322 endmember library in Table DR3 (see footnote 1). 


\section{Accepted, Pre-Copy Edit version}
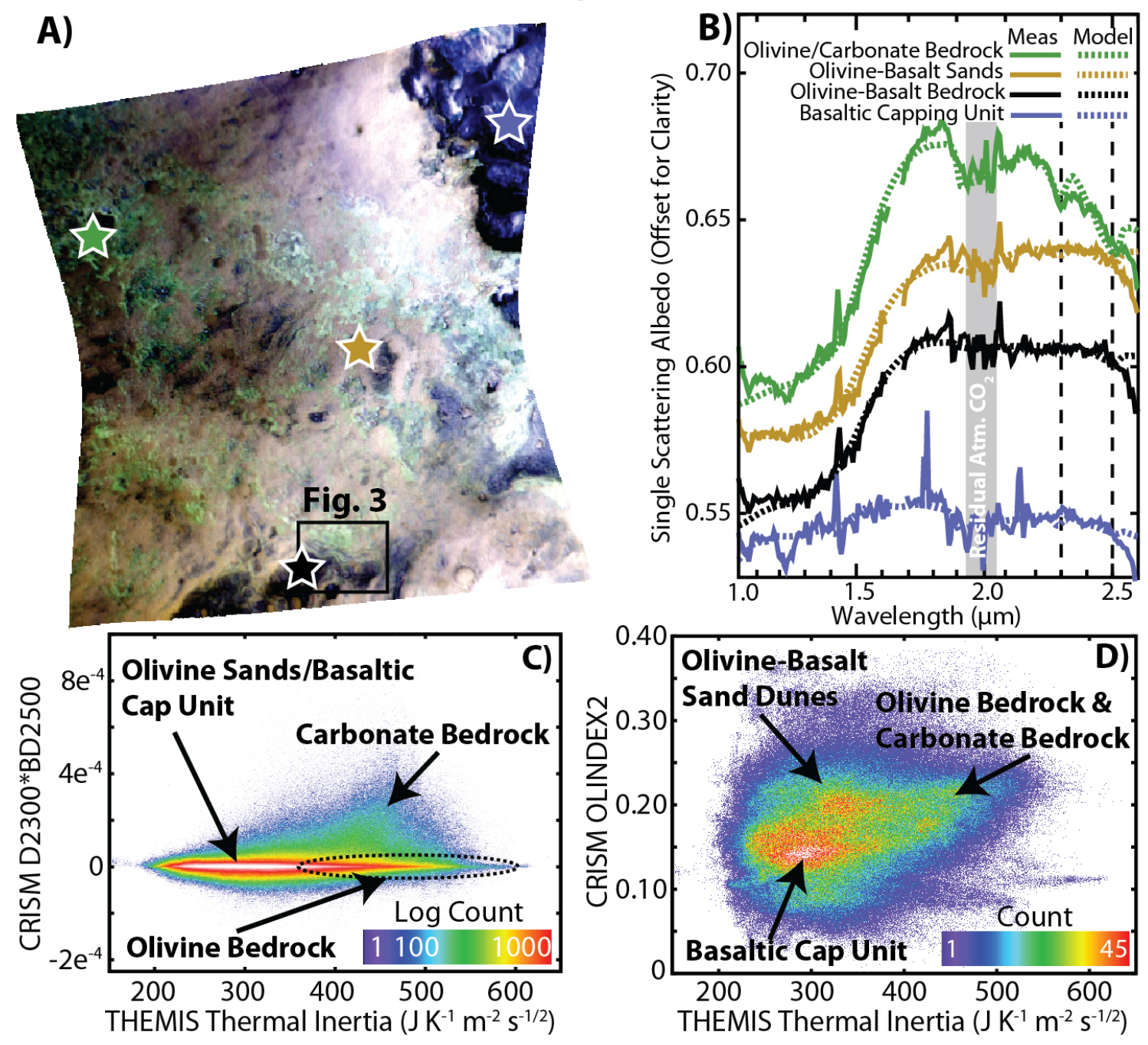

325 Figure 2. A: CRISM (FRT000C968) SSA image (RGB; 2.38, 1.80, $1.15 \mu \mathrm{m}$ ), where

326 green indicates carbonate-bearing material, brown/yellow correlates with olivine-basalt

327 sands and purple is typical of the basaltic capping unit and dark-toned olivine-enriched

328 units. B: SSA spectra and forward Hakpe model fits from the locations identified in A.

329 Each spectrum corresponds to a unique morphology highlighted in Fig. 3. C,D: CRISM

330 band indices THEMIS TI for the region in Fig. 1. 
Accepted, Pre-Copy Edit version
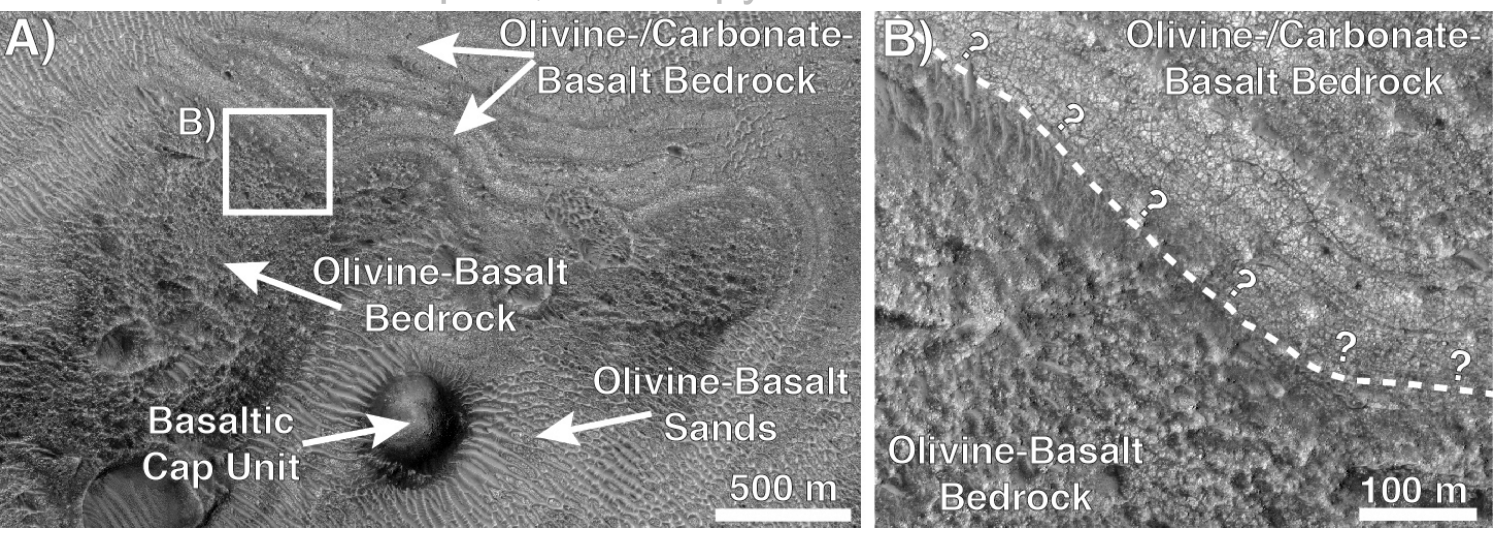

Figure 3. HiRISE image (PSP_010351_2020). A: Contact between the basaltic cap unit

334 and underlying bedrock, plus olivine-basalt sands atop the olivine-/carbonate-enriched

335 bedrock. B: Potential contact between the carbonate-bearing bedrock and the overlying

336 olivine-basalt bedrock. 

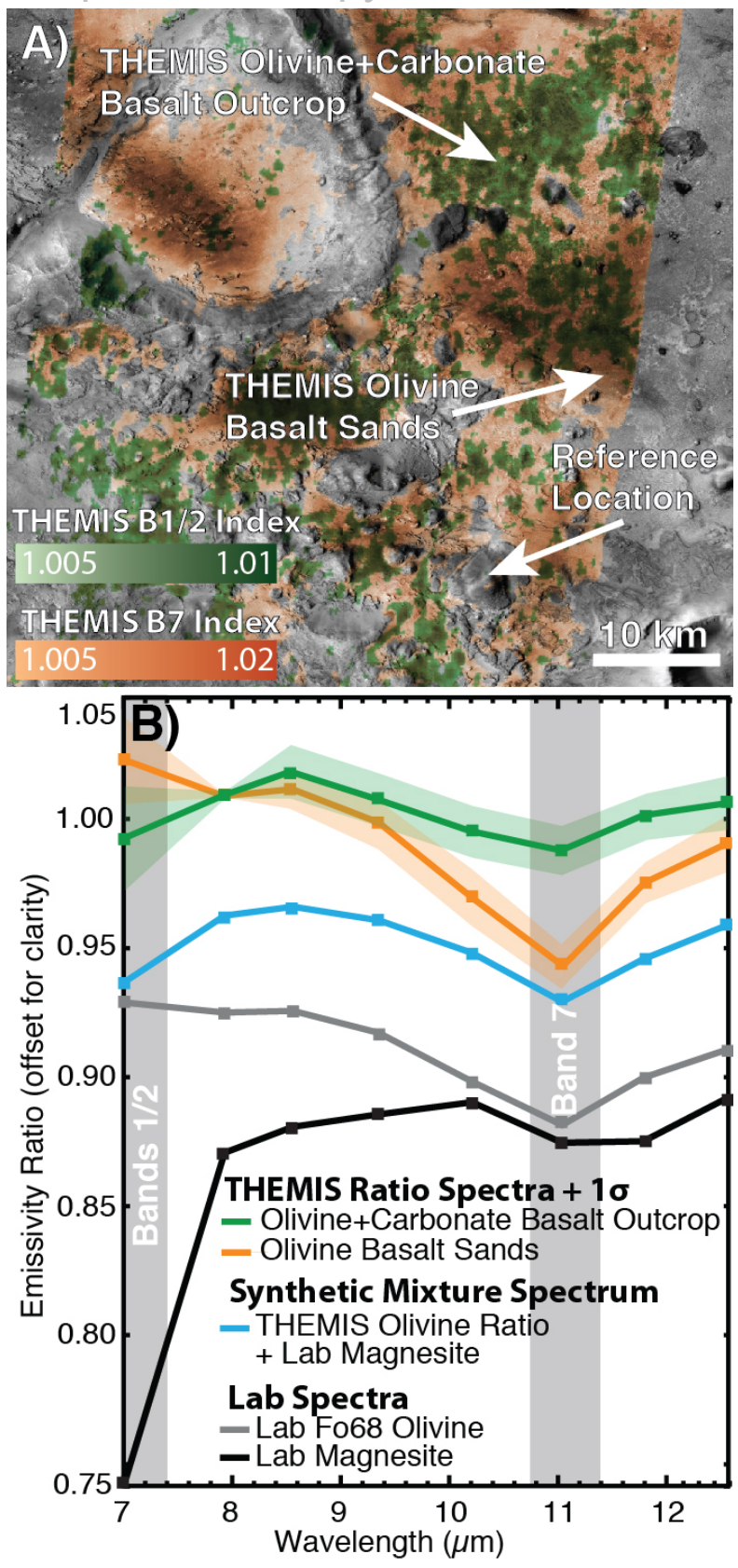

339 Figure 4. A: THEMIS carbonate (band 1+2 downturn) and olivine (band 7 band depth)

340 indices (I36276032). B: THEMIS ratio and laboratory spectra of the Fe-Mg carbonate

341 solid solution. Ratio spectra are from $\sim 0.5 \times 0.5 \mathrm{~km}$ areas on the olivine/carbonate-

342 bearing basalt outcrops (green) and olivine-bearing basalt sands (orange) with 1- $\sigma$

343 deviations on the average. The spectra of a synthetic mixture (cyan) of THEMIS olivine 


\section{Geology, 2015, doi: 10.1130/G36983.1 \\ Accepted, Pre-Copy Edit version}

344 sand ratio and laboratory carbonate (magnesite, black) spectra matches that of THEMIS

345 spectrum of the carbonate-bearing, olivine basalt outcrops.

346

Page 21 of 33 


\section{SUPPLEMENTARY MATERIALS}

$348 \quad 1.1 \quad T E S$ Data Analysis: Index Mapping and Deconvolution

349 TES data in this work were mapped using the Glotch and Rogers (2013) spectral

350 index, which highlights long-wavelength spectral features due to $\mathrm{Fe} / \mathrm{Mg}$-carbonates and

351 their decomposition products, in order to discriminate potential carbonate-bearing

352 localities to perform TES quantitative analysis. Data for mapping and quantitative

353 analysis were limited to locations with well-calibrated, clear atmosphere and warm

354 surface temperatures $(>250 \mathrm{~K}, 9 \mu \mathrm{m}$ dust extinction $<0.17,11 \mu \mathrm{m}$ ice extinction $<0.04$,

355 TES Lambert albedo $<0.18$, emission angles $<5^{\circ}$, no solar panel or mirror motion, and

356 orbit counter keeper (OCK) values $<7000)$. Mineral abundance determination and

357 atmospheric correction was performed by modeling each TES emissivity spectrum with a

358 library of mineral spectra (Table S3) and atmospheric components (Bandfield et al.,

359 2000), using non-negative linear least-squares fitting (Rogers and Aharonson, 2008;

360 Smith et al., 2000). This atmospheric/surface separation technique and endmember

361 mineral deconvolution is commonly employed to determine mineral abundances to $\sim 5$ -

$36210 \%$ absolute areal abundance for minerals above the typical $\sim 10 \%$ detection limit (Table

363 S1) (Feely and Christensen, 1999; Ramsey and Christensen, 1998).

\subsection{CRISM Data Analysis: Selection and Non-Linear Mixing}

365 CRISM I/F data were atmospherically corrected using the volcano scan method

366 (Murchie et al., 2009) and processed into spectral index parameters (Pelkey et al., 2007)

367 to map the spatial distribution of carbonate (BD2300 \& BD2500 (Ehlmann et al., 2008))

368 and olivine (OLINDEX2 (Salvatore et al., 2010)) and to identify locations with the

369 strongest absorptions from which spectra were then extracted (Fig. 2). A single CRISM 
370 image (FRT0000C968) was processed through the Discrete Ordinate Radiative Transfer

371 (DISORT) atmospheric retrieval algorithm, solving for carbon dioxide, water vapor,

372 carbon monoxide, and associated Rayleigh scattering and discrete gas absorptions for

$373 \mathrm{CO}_{2}, \mathrm{H}_{2} \mathrm{O}$, and $\mathrm{CO}$ (Arvidson et al., 2014; Stamnes et al., 1988; Wiseman et al., 2012).

374 These data were processed to single scattering albedo (SSA) to enable numerical

375 modeling of the spectra by two methods (Ehlmann et al., 2011b): (1) a Hapke -style

376 (Hapke, 1993) radiative transfer unmixing model that uses the optical constants of phases

377 of interest (Table S4) to simultaneously solve for phase abundance and grain size by

378 downhill simplex minimization of error between measured and modeled spectra over the

3791.20 to $2.56 \mu \mathrm{m}$ wavelength range; and (2) a forward model that uses laboratory-derived

380 optical constants for magnesite with a scene-derived olivine-basalt spectrum to establish

381 a relationship between band depth, single scattering albedo, and abundance for given

382 mixing ratios and grain sizes of olivine-basalt and carbonate. Approach 2 assumes that

383 the major compositional difference between the olivine-basalt bedrock and the carbonate-

384 bearing materials is the addition of carbonate, an assumption warranted by TES and

385 approach 1 results, discussed further herein. Note that in Approach 2, band depth at 2.3

$386 \mu \mathrm{m}$, band depth at $2.5 \mu \mathrm{m}$, and SSA each bound the maximum possible carbonate. They

387 must also produce simultaneously consistent values. Thus, while the albedo of the deposit

388 permits up to $25 \mathrm{wt} . \% \mathrm{Mg}$-carbonate mixed with basalt, the observed depth of the $2.5-\mu \mathrm{m}$

389 absorption in carbonate suggests the upper bound to be about 5 wt.\%.

$390 \quad 1.3 \quad$ THEMIS Data Analysis: Composition and Thermophysics

391 Spectral ratios are commonly used when analyzing CRISM data but are rarely

392 calculated with THEMIS data. Spectral ratios do not require fully atmospherically 


\section{Geology, 2015, doi: 10.1130/G36983.1 \\ Accepted, Pre-Copy Edit version}

393 corrected THEMIS images, which is advantageous in this region because coincident

394 THEMIS and TES data that meet the requirements for a high quality correction are

395 limited (Bandfield et al., 2004). All other THEMIS standard processing procedures were

396 followed (Edwards et al., 2011). Due to the low signal-to-noise ratios (SNR) of bands 1

$397 \& 2(6.78 \mu \mathrm{m})$, originally designed to map carbonates (Christensen et al., 2004), our use

398 of THEMIS spectral data is limited to spectral ratios and not quantitative unmixing;

399 THEMIS is used primarily to highlight spectral differences between terrains. Two

400 spectral indices, band $1 / 2$ downturn and band 7 band depth, were developed to map

401 olivine and carbonate-related spectral parameters over the region.

402 THEMIS thermal inertia data were also modeled over the entire region (Fergason

403 et al., 2006). Thermal inertia data are sensitive to small changes in particle size (Piqueux

404 and Christensen, 2011; Presley and Christensen, 1997) and are exceptionally sensitive to

405 small volumes of pore filling cements (Piqueux and Christensen, 2009). We use these

406 data in conjunction with spectral data to identify and map distinct compositional and

407 thermophysical groupings. 

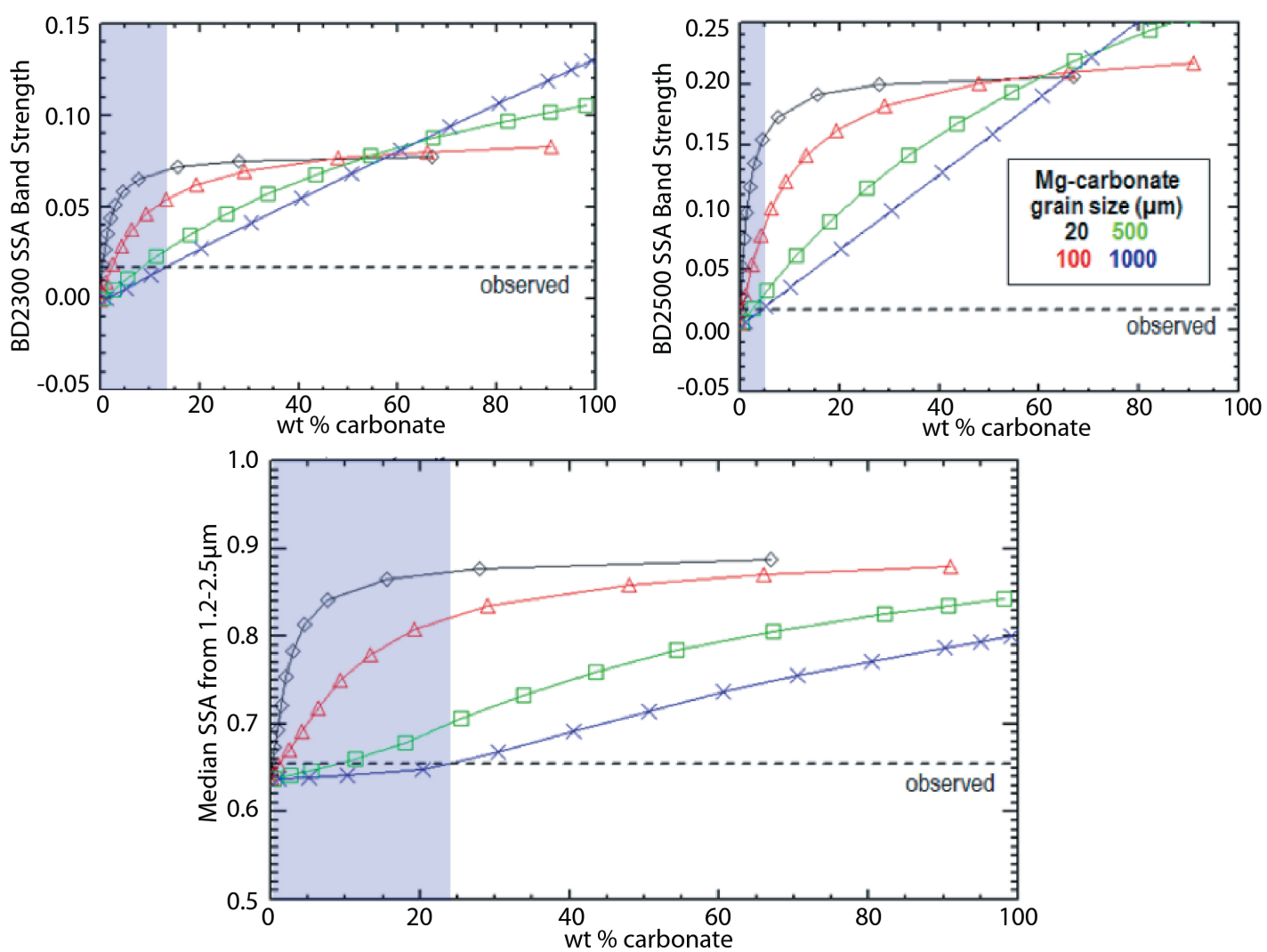

410 Figure DR1. Modeled infrared single scattering albedo (SSA), band depth at $2300 \mathrm{~nm}$

411 (BD2300), and band depth at $2500 \mathrm{~nm}$ (BD2500) for mixtures of carbonate with the

412 olivine-enriched rock at Nili Fossae. Forward modeling was performed to generate

413 simulated mixture spectra. The derived SSA olivine rock endmember spectrum from the

414 CRISM scene was mixed with the SSA spectrum of magnesium carbonate from our

415 optical constant library at different abundances. Grain size of the olivine-bearing rocks

416 was assumed to be $1 \mathrm{~mm}$, based on Hapke inverse modeling results and THEMIS thermal

417 inertia. The carbonate grain size was varied. All runs with the three parameters indicate

418 carbonate abundances are lower than 25\%. Observed BD2500 suggests abundances $\leq 5 \%$. 


\section{Geology, 2015, doi: 10.1130/G36983.1 Accepted, Pre-Copy Edit version}

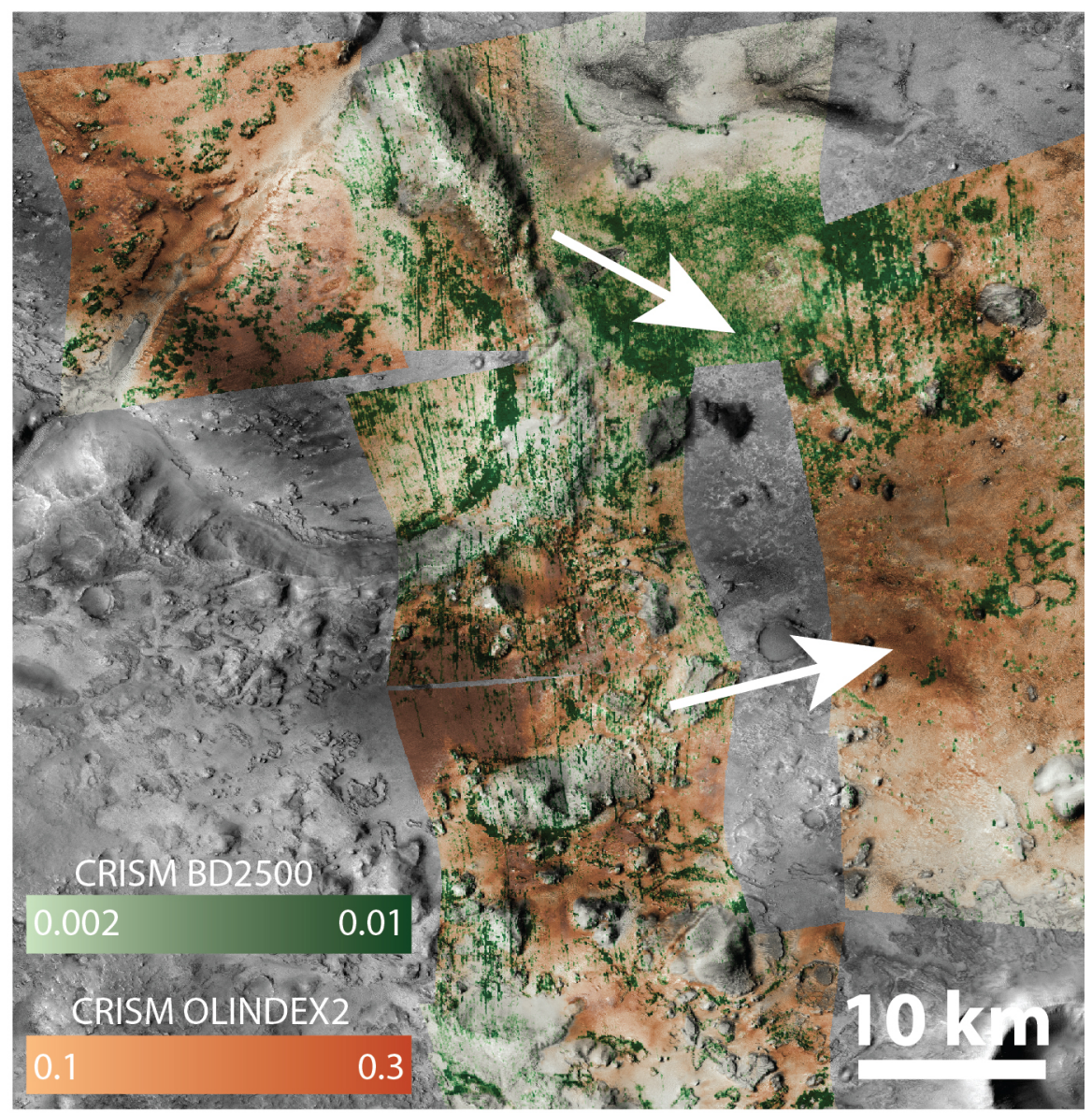

420 Figure DR2. CRISM BD2500 and OLINDEX2 band parameter maps over the same

421 region as Fig. 4a. Linear streaks are artifacts in the image and not associated with surface 422 features. 

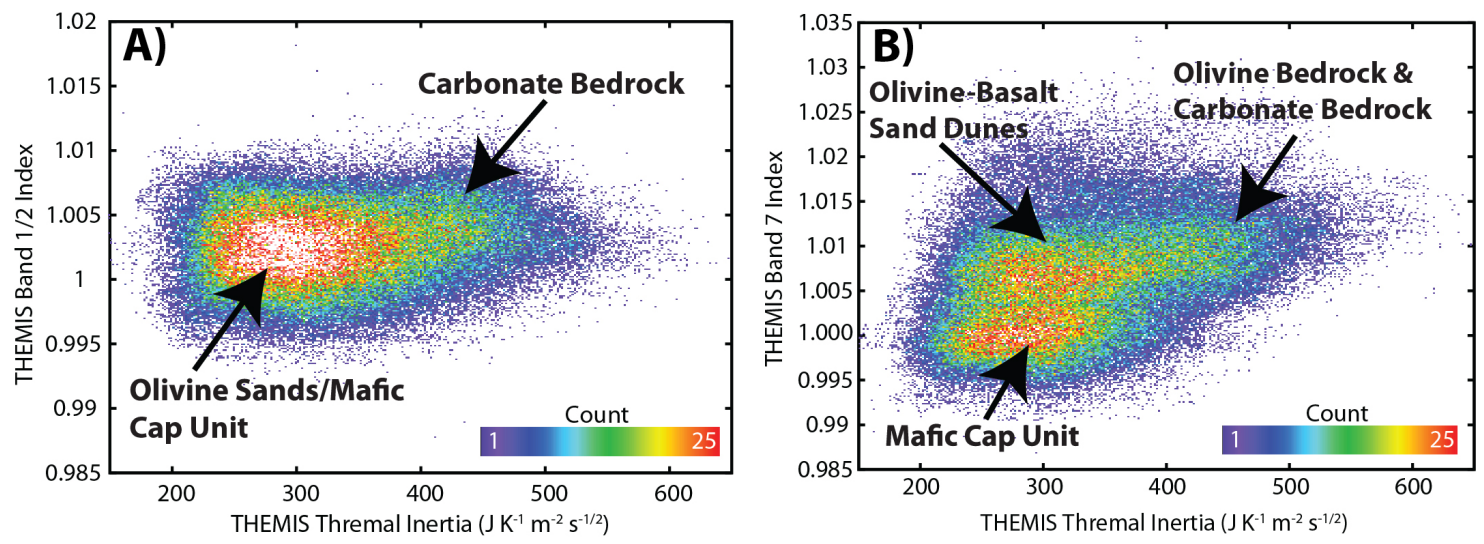

425 Figure DR3. Density plots of THEMIS band indices (Fig. 4a) for A: band $1 \& 2$ index

426 and B: band 7. THEMIS TI over the region shown. Only the locations where both

427 datasets were present are plotted. 


\section{SUPPLEMENTARY TABLES}

Table DR1: TES model mineral abundances (\%),

Values reported in parentheses are $\pm 1 \sigma$ for derived abundances.

\begin{tabular}{cccc}
\hline Mineral & TES $^{\text {A\&B }}$ & TES & Syrtis Type $^{\mathbf{b}}$ \\
\hline Pyroxene & $21(8)$ & $27(7)$ & $32(3)$ \\
Olivine & $21(4)$ & $4(5)$ & $5(3)$ \\
High-Si Phases & $24(8)$ & $20(7)$ & $19(10)$ \\
Carbonate & $15(4)$ & $10(1)$ & $7(1)$ \\
Feldspar & $11(7)$ & $30(10)$ & $27(6)$ \\
Other $^{\mathrm{a}}$ & $8(3)$ & $9(3)$ & $10(2)$ \\
RMS Fit Error $^{\text {R }}$ & 0.35 & 0.35 & 0.14 \\
\hline
\end{tabular}

${ }^{\text {a}}$ Values reported in the "Other" category include phases like hematite, sulfate, and quartz.

${ }^{b}$ Values from Rogers and Christensen (2007) of nearby

Hesperian basalt for comparison

Table DR2: CRISM Derived abundances (wt \% \& grain size)

\begin{tabular}{|c|c|c|c|c|}
\hline Phase & $\begin{array}{c}\text { Carbonate } \\
\text { Bedrock }\end{array}$ & $\begin{array}{c}\text { Dark } \\
\text { Bedrock }\end{array}$ & Dunes & $\begin{array}{c}\text { Capping } \\
\text { Unit }\end{array}$ \\
\hline \multirow{2}{*}{ Carbonate } & 15 & 1 & 8 & $1^{\#}$ \\
\hline & $(1 \mathrm{~mm})$ & $(12 \mu \mathrm{m})$ & $(1 \mathrm{~mm})$ & $(23 \mu \mathrm{m})$ \\
\hline \multirow{2}{*}{ Olivine } & 24 & 26 & 25 & 5 \\
\hline & $(\sim 1 \mathrm{~mm})$ & $(\sim 1 \mathrm{~mm})$ & $(\sim 1 \mathrm{~mm})$ & $(384 \mu \mathrm{m})$ \\
\hline \multirow{2}{*}{ Basalt } & 59 & 70 & 65 & 89 \\
\hline & $(950 \mu \mathrm{m})$ & $(560 \mu \mathrm{m})$ & $(770 \mu \mathrm{m})$ & $(394 \mu \mathrm{m})$ \\
\hline Other* & 2 & 2 & 2 & 5 \\
\hline RMS Fit Error & 0.0038 & 0.0023 & 0.0033 & 0.0023 \\
\hline $\begin{array}{l}\text { TI-Derived } \\
\text { Grain Size }\end{array}$ & $\gtrsim 1 \mathrm{~mm}$ & $\gtrsim 1 \mathrm{~mm}$ & $\gtrsim 1 \mathrm{~mm}$ & $\begin{array}{c}\sim 300-700 \\
\mu \mathrm{m}\end{array}$ \\
\hline
\end{tabular}

*Values reported in the "Other" category include phases like dust, additional feldspar \& nontronite.

\#Ill-fit; carbonate and nontronite introduce an absorption not present in the data. A hydrated phase not in our optical constant libraries is needed to account for the overall continuum shape. ^Grain Sizes 
Table DR3: Library Mineral Endmembers for Linear Spectral Mixture Analysis of TES Data ${ }^{\mathrm{a}}$

\begin{tabular}{|c|c|}
\hline Mineral & Group \\
\hline Quartz BUR-4120 & Quartz \\
\hline Microcline BUR-3460 & Feldspar \\
\hline Albite WAR-0235 & Feldspar \\
\hline Oligoclase BUR-060D & Feldspar \\
\hline Andesine WAR-0024 & Feldspar \\
\hline Labradorite BUR-3080A & Feldspar \\
\hline Bytownite WAR-1384 & Feldspar \\
\hline Anorthite BUR-340 & Feldspar \\
\hline Shocked An $17 \mathrm{GPa}^{\mathrm{b}}$ & Feldspar \\
\hline Shocked An $21 \mathrm{GPa}^{\mathrm{b}}$ & Feldspar \\
\hline Shocked An $25.5 \mathrm{GPa}^{\mathrm{b}}$ & Feldspar \\
\hline Shocked An $27 \mathrm{GPa}^{\mathrm{b}}$ & Feldspar \\
\hline Shocked An $38.2 \mathrm{GPa}^{\mathrm{b}}$ & Feldspar \\
\hline Shocked An $56.3 \mathrm{GPa}^{\mathrm{b}}$ & Feldspar \\
\hline Bronzite NMNH-93527 & Pyroxene \\
\hline Enstatite HS-9.4B & Pyroxene \\
\hline Hypersthene NMNH-B18247 & Pyroxene \\
\hline Pigeonite $^{c}$ & Pyroxene \\
\hline Diopside & Pyroxene \\
\hline Augite NMNH-9780 & Pyroxene \\
\hline Augite NMNH-122302 ${ }^{\mathrm{c}}$ & Pyroxene \\
\hline Hedenbergite DSM-HED01 & Pyroxene \\
\hline Forsterite BUR-3720A & Olivine \\
\hline Fayalite WAR-RGFAY01 & Olivine \\
\hline Olivine Fo60 KI3362 ${ }^{\mathrm{d}}$ & Olivine \\
\hline Olivine Fo68 KI3115 ${ }^{\mathrm{d}}$ & Olivine \\
\hline Olivine Fo35 KI3373 ${ }^{\mathrm{d}}$ & Olivine \\
\hline Olivine Fo10 KI3008 ${ }^{\mathrm{d}}$ & Olivine \\
\hline Illite IMt-1 & High-Si Phase \\
\hline Montmorillonite STx-1 & High-Si Phase \\
\hline Saponite SpNv-1 & High-Si Phase \\
\hline Montmorillonite SWy-1 & High-Si Phase \\
\hline K-rich glass ${ }^{\mathrm{e}}$ & High-Si Phase \\
\hline $\mathrm{SiO} 2$ glass $^{\mathrm{e}}$ & High-Si Phase \\
\hline Opal-A 02-011 ${ }^{\mathrm{f}}$ & High-Si Phase \\
\hline Aluminous opal ${ }^{\mathrm{g}}$ & High-Si Phase \\
\hline Heulandite ${ }^{\mathrm{h}}$ & High-Si Phase \\
\hline Stilbite $^{\text {h }}$ & High-Si Phase \\
\hline Avg. Martian hematite ${ }^{\mathrm{i}}$ & Hematite \\
\hline Anhydrite S9 & Sulfate \\
\hline
\end{tabular}




\begin{tabular}{ll}
\hline Gypsum S6 & Sulfate \\
Kieserite & Sulfate \\
Calcite C40 & Carbonate \\
Dolomite C20 & Carbonate \\
Magnesite MAGBB-1 & Carbonate \\
Siderite SIDIG-1 & Carbonate \\
\hline a) All samples are from the ASU spectral library available at \\
http://speclib.asu.edu Christensen et al. (2000) unless otherwise noted \\
b) Johnson et al. (2002) \\
c) Provided by V. E. Hamilton, described by Hamilton (2000) \\
d) Described by Koeppen and Hamilton (2008) \\
e) Described by Wyatt et al. (2001) \\
f) Described by Michalski et al. (2003) \\
g) Provided by M. D. Kraft \\
h) Described by Ruff (2004) \\
i) Derived from TES data, described by Glotch et al. (2004) \\
j) Described by Glotch and Rogers (2013) \\
\hline
\end{tabular}

Table DR4: Optical constants used for Hapke spectral unmixing of CRISM data. A variety of runs with greater and fewer constants (max of 7 per run) were executed with fitting over the wavelength range 1200$2560 \mathrm{~nm}$. Those used in the final best-fit presented in the paper are indicated in the main text. The cap unit cannot be well-modeled with the same set as the olivine-bearing materials to produce an acceptable fit, pointing to a substantially different composition. Specifically, the continuum shape requires a hydrated phase, but inclusion of carbonate and nontronite leads to absorptions in modeled data that are not present in the actual data. The basaltic cap spectrum remained relatively ill-fit (Fig. 2 ) at the longest wavelengths (3- $\mu$ m downturn) due to lack of an appropriate library optical constant match of the hydrated phase.

\begin{tabular}{ll}
\hline Phase & References \\
\hline Olivine & Ehlmann et al. $(2011 a ; 2011 b)$ \\
Magnesite & Ehlmann et al. $(2011 a ; 2011 b)$ \\
Basalt & Ehlmann et al. $(2011 a ; 2011 b)$ \\
Feldspar (w/ magnetite inclusions) & Poulet et al. $(2008)$ \\
Pyroxene & Poulet et al. $(2008)$ \\
Dust & Wolff et al. $(2009)$ \\
Nontronite (NG-1) & Ehlmann et al. $(2011 a ; 2001 b)$ \\
\hline
\end{tabular}




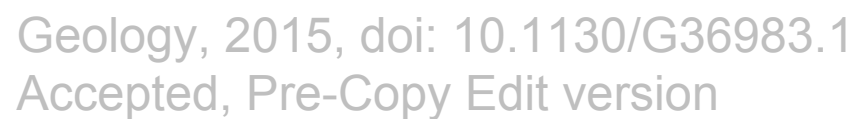

\section{SUPPLEMENTARY REFERNCES}

Arvidson, RE, et al., 2014, Ancient aqueous environments at Endeavour crater, Mars: Science, v. 343 , no. 6169 , p. 1248097

Bandfield, JL, et al., 2004, Atmospheric correction and surface spectral unit mapping using Thermal Emission Imaging System data: J. Geophys. Res., v. 109, p. E10008

Bandfield, JL, Smith, MD, and Christensen, PR, 2000, Spectral dataset factor analysis and endmember recovery: Application to analysis of martian atmospheric particulates: J. Geophys. Res., v. 105, p. 9573-9588

Christensen, PR, et al., 2000, A thermal emission spectral library of rock-forming minerals: Journal of Geophysical Research, v. 105, no. E4, p. 9735-9739

Christensen, PR, et al., 2004, The Thermal Emission Imaging System (THEMIS) for the Mars 2001 Odyssey Mission: Space Science Reviews, v. 110, no. 1, p. 85130

Edwards, CS, et al., 2011, Mosaicking of global planetary image datasets: 1 . Techniques and data processing for Thermal Emission Imaging System (THEMIS) multi-spectral data: J. Geophys. Res., v. 116, no. E10, p. E10008

Ehlmann, BL, et al., 2011a, CRISM-derived mineral abundances at the MSL landing sites: The Fifth Mars Science Laboratory Landing Site Workshop, p. May 1618, Monrovia, Ca

Ehlmann, B, et al., 2011b, Estimating Modal Mineralogy of Mixtures with Phyllosilicates Using Radiative Transfer Modeling of Visible/Near Infrared Spectra, in Proceedings Lunar and Planetary Institute Science Conference Abstracts, Volume 42, p. 1704.

Ehlmann, BL, et al., 2008, Orbital identification of carbonate-bearing rocks on Mars: Science, v. 322, no. 5909, p. 1828

Feely, KC, and Christensen, PR, 1999, Quantitative compositional analysis using thermal emission spectroscopy: Application to igneous and metamorphic rocks: J. Geophys. Res., v. 104, p. 24,195-124,210

Fergason, RL, Christensen, PR, and Kieffer, HH, 2006, High resolution thermal inertia derived from THEMIS: Thermal model and applications: J. Geophys. Res., v. 111, p. E12004

Glotch, TD, et al., 2004, Effect of precursor mineralogy on the thermal infrared emission spectra of hematite: Application to martian hematite mineralization: J. Geophys. Res., v. 109, p. E07003

Glotch, TD, and Rogers, AD, 2013, Evidence for magma-carbonate interaction beneath Syrtis Major, Mars: J. Geophys. Res, v. 118, no. 1, p. 126-137

Hamilton, VE, 2000, Thermal infrared emission spectroscopy of the pyroxene mineral series: J Geophys Res-Planet, v. 105, no. E4, p. 9701-9716

Hapke, B, 1993, Combined Theory of Reflectance and Emittance Spectroscopy, in Pieters, CM, and Englert, PAJ, eds., Remote Geochemical Analysis: Elemental and Mineralogical Composition: Cambridge, Cambridge University Press

Johnson, JR, et al., 2002, Thermal infrared spectroscopy of experimentally shocked anorthosite and pyroxentie: Implications for remote sensing of Mars: J. Geophys. Res., v. 107(E10), p. 5073 


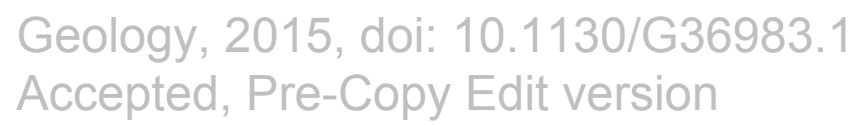

Koeppen, WC, and Hamilton, VE, 2008, Global distribution, composition, and abundance of olivine on the surface of Mars from thermal infrared data: J. Geophys. Res, v. 113, p. E05001

Michalski, JR, et al., 2003, Thermal emission spectroscopy of the silica polymorphs and considerations for remote sensing of Mars: Geophys. Res. Lett., v. 30, no. 19 , p. 2008

Murchie, SL, et al., 2009, Compact Reconnaissance Imaging Spectrometer for Mars investigation and data set from the Mars Reconnaissance Orbiter's primary science phase: J. Geophys. Res., v. 114

Pelkey, SM, et al., 2007, CRISM multispectral summary products: Parameterizing mineral diversity on Mars from reflectance: J. Geophys. Res, v. 112, p. E08S14

Piqueux, S, and Christensen, PR, 2009, A model of thermal conductivity for planetary soils: 2. Theory for cemented soils: J. Geophys. Res., v. 114, no. E09006

Piqueux, S, and Christensen, PR, 2011, Temperature-dependent thermal inertia of homogeneous Martian regolith: J. Geophys. Res., v. 116, p. E07004

Poulet, F, et al., 2008, Abundance of minerals in the phyllosilicate-rich units on Mars: Astronomy \& Astrophysics, v. 487, no. 2, p. L41-U193

Presley, MA, and Christensen, PR, 1997, Thermal conductivity measurements of particulate materials, Part I: A review: J. Geophys. Res., v. 102, no. E3, p. 6535-6549

Ramsey, MS, and Christensen, PR, 1998, Mineral abundance determination: Quantitative deconvolution of thermal emission spectra: J. Geophys. Res., v. 103 , p. $577-596$

Rogers, AD, and Aharonson, 0, 2008, Mineralogical composition of sands in Meridiani Planum determined from Mars Exploration Rover data and comparison to orbital measurements: J. Geophys. Res., v. 113, p. E06S14

Rogers, AD, and Christensen, PR, 2007, Surface mineralogy of martian low-albedo regions from MGS TES data: Implications for crustal evolution and surface alteration: J. Geophys. Res., v. 112, p. E01003

Ruff, SW, 2004, Spectral evidence for zeolite in the dust on Mars: Icarus, v. 168, no. 1, p. 131-143

Salvatore, MR, et al., 2010, Definitive evidence of Hesperian basalt in Acidalia and Chryse planitiae: J. Geophys. Res., v. 115, p. E07005

Smith, MD, Bandfield, JL, and Christensen, PR, 2000, Separation of atmospheric and surface spectral features in Mars Global Surveyor Thermal Emission Spectrometer (TES) spectra: Models and atmospheric properties: J. Geophys. Res., v. 105, no. E4, p. 9589-9608

Stamnes, K, et al., 1988, Numerically stable algorithm for discrete-ordinate-method radiative transfer in multiple scattering and emitting layered media: Appl Opt, v. 27, no. 12 , p. 2502-2509

Wiseman, S, et al., Retrieval of atmospherically corrected CRISM spectra using radiative transfer modeling, in Proceedings Lunar and Planetary Institute Science Conference Abstracts2012, Volume 43, p. 2146.

Wolff, MJ, et al., 2009, Wavelength dependence of dust aerosol single scattering albedo as observed by the Compact Reconnaissance Imaging Spectrometer: J Geophys Res-Planet, v. 114, no. E2 


\section{Geology, 2015, doi: 10.1130/G36983.1 \\ Accepted, Pre-Copy Edit version}

525 Wyatt, MB, et al., 2001, Analysis of terrestrial and martian volcanic compositions using thermal emission spectroscopy: I. Determination of mineralogy, chemistry, and classification strategies: J. Geophys. Res., v. 106, no. E7, p. $14,711-714,732$

530 